\title{
A homozygous kinase-defective mutation in the insulin receptor gene in a patient with leprechaunism
}

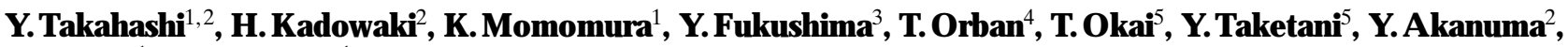 \\ Y.Yazaki ${ }^{1}$, T. Kadowaki ${ }^{1}$ \\ ${ }^{1}$ Third Department of Internal Medicine, Faculty of Medicine, University of Tokyo, Tokyo, Japan \\ ${ }^{2}$ Institute for Diabetes Care and Research, Asahi Life Foundation, Tokyo, Japan \\ ${ }^{3}$ Saitama Children's Medical Center, Iwatsuki, Japan \\ ${ }^{4}$ Tawam Hospital, Abu Dhabi, United Arab Emirates \\ ${ }^{5}$ Department of Obstetrics and Gynecology, Faculty of Medicine, University of Tokyo, Tokyo, Japan
}

Summary We report a homozygous missense mutation at position 1092 (substitution of glutamine for arginine) in the tyrosine kinase domain of the insulin receptor in a patient with leprechaunism associated with severe insulin resistance and intrauterine growth retardation. Site-directed mutagenesis as well as analyses of the patient's lymphocytes revealed that this mutation causes a marked decrease in tyrosine kinase activity of the insulin receptor without any defect in insulin binding, which causes severe defects in insulin-stimulated glucose transport, glycogen synthesis and DNA synthesis. Thus, this is the first homozygous mutation resulting in a selective-kinase defect of the insulin receptor. Interestingly, the parents who are cousins and are heterozygous for the mutation have type A insulin resistance syndrome. This correlation between genotype and phenotype in a single pedigree suggests that the severity of the mutation will determine the phenotype. Based upon this assumption, we have been successful in prenatal diagnosis of the fifth child. Furthermore, we have demonstrated the effectiveness of clinical administration of insulin-like growth factor-I (IGF-I) in this patient and in vitro analysis of the patient's skin fibroblasts, suggesting that IGF-I can compensate for insulin action via the IGF-I receptor in a patient almost lacking functional insulin receptors. [Diabetologia (1997) 40: 412-420]

Keywords Insulin resistance syndrome, mutation, genotype, phenotype, tyrosine kinase.
Leprechaunism is the most severe form of the insulin resistance syndrome and is characterized by marked insulin resistance, severe growth retardation, subcutaneous lipoatrophy, acanthosis nigricans, hirsutism and paradoxical fasting hypoglycaemia. Mutations in both alleles of the insulin receptor (IR) gene have been identified in patients with this syndrome, indicating that this is a genetic disease caused by IR gene mutations [1-6]. Type A insulin resistance is

Received: 25 September 1996 and in revised form: 10 December 1996

Corresponding author: Dr. T. Kadowaki, Third Department of Internal Medicine, Faculty of Medicine, University of Tokyo, 7-3-1 Hongo, Bunkyo-ku, Tokyo, Japan 113

A bbreviations: IR, Insulin receptor; IGF-1, insulin-like growth factor-1; IRI, immunoreactive insulin; PMSF, phenylmethylsulphonyl fluoride; CHO, Chinese hamster ovary cells; IRS-1, insulin-receptor substrate-1. another form of the insulin resistance syndrome, and some patients with the type A syndrome have been found to have mutations in the IR gene [1-4, 7-10]. Patients with the type A syndrome sometimes have mutations in both alleles of the IR gene, while missense mutations in the tyrosine kinase domain of the IR cause type A insulin resistance with only one affected allele [8-16]. Such mutations are called a dominant-negative mutation which decreases tyrosine kinase activity of IR by $75 \%$ in vivo. At least three different hypotheses have been proposed to explain the difference in phenotypes of the insulin resistance syndromes associated with IR mutations: 1) severity of insulin resistance; 2) existence of branched pathway; and 3) genetic variation at different loci [1].

The first hypothesis proposes that the severity of the mutation in the IR gene causes the difference in insulin resistance and determines the clinical syndromes; patients with mutations in both alleles of 
the IR gene would present a more serious form of the insulin resistance syndrome than those with mutations in only one allele. The second hypothesis proposes that a mutant IR might be impaired in its ability to mediate one biological action while retaining its ability to mediate another; leprechaunism might result from an impairment in both glucose metabolism and the growth-promoting effect mediated by IR, while the type A syndrome might result from a defect only in the metabolic action. The third hypothesis is based upon several publications arguing for the presence of defects in other growth factor receptors in leprechaunism such as the insulin-like growth factorI (IGF-I) receptor and epidermal growth factor receptor; the type A syndrome might be caused only by mutations in the IR gene, and leprechaunism by mutations in both the IR gene and other growth factor receptor gene(s).

More than 50 kinds of mutations in the IR gene have now been reported [1-22], and understanding of the effects of a homozygous deletion [21], a homozygous nonsense mutation [20, 22] and dominantnegative mutations on the phenotype allows us to predict that the severity of the mutation and the subsequent insulin resistance determine the phenotype. However, there has been no report on an appropriate family with the insulin resistance syndrome showing a more definite correlation between the genotype of IR mutation and the phenotype.

We describe here the genetic analysis of a single pedigree where the two forms of typical insulin resistance syndromes, leprechaunism and type A insulin resistance co-exist. We have also studied a mechanism whereby IGF-I is used as a therapeutic agent for the insulin resistance syndrome at a cellular level. Additionally, we describe the successful prenatal diagnosis of the family's fifth child.

\section{Subjects and methods}

The proband was an Arabic boy of 1 year of age, who was born as the fourth child at 36 weeks of gestation with an abnormally low birth-weight $(1100 \mathrm{~g})$. He had severe insulin-resistant diabetes (blood glucose $24.8 \mathrm{mmol} / \mathrm{l}$ and corresponding immunoreactive insulin (IRI) $55050 \mathrm{pmol} / \mathrm{l}$ ), severe growth retardation, acanthosis nigricans, subcutaneous lipoatrophy, and other features typical of leprechaunism. His parents were consanguineous and had some typical features of type A insulin resistance syndrome including acanthosis nigricans of the neck and hypertrichosis of the back without obesity or growth retardation. The father, 27 years of age, was diagnosed with overt diabetes mellitus with elevated fasting blood glucose $(7.7 \mathrm{mmol} / \mathrm{l})$, moderately increased fasting IRI (438 pmol/l) and haemoglobin $\mathrm{A}_{1 \mathrm{c}}(7.3 \%)$ but had received no therapy. The mother was 26 years old and had mild fasting hyperinsulinaemia (216 pmol/l), but the corresponding fasting blood glucose $(4.0 \mathrm{mmol} / \mathrm{l})$ and haemoglobin $\mathrm{A}_{1 \mathrm{c}}(5.1 \%)$ were within the normal range, and she did not have diabetes or polycystic ovary syndrome. The child's eldest brother also had the features of leprechaunism and had died at 7 years of age, while the second and the third boys were clinically normal.

For the genetic analysis of the family, the clinical trial of IGF-I to the proband, and the prenatal diagnosis, informed consent was obtained from both of the parents. The investigations were performed in accordance with the principles of the Declaration of Helsinki.

\section{Study in cultured lymphocytes}

We established Epstein-Barr virus-transformed lymphocytes from the proband and his parents. ${ }^{125}$ I-insulin binding study in these cells was performed as previously described by Yamamoto et al. [23], where non-specific binding was assessed in the presence of $1 \mu \mathrm{mol} / \mathrm{l}$ of unlabelled insulin. In vitro autophosphorylation of the insulin receptor partially purified from transformed lymphocytes with wheat-germ agglutinin was performed as previously described [23], in which the content of IRs was normalized by immunoblot analysis before the phosphorylation assay. Tyrosine phosphorylation was detected by immunoblot analysis with anti-phosphotyrosine antibody and ${ }^{125}$ I-protein A.

In vitro tyrosine kinase assay of the IR from cultured lymphocytes was performed with a slight modification of previously described protocols [23-26]. Cells were lysed with icecold solubilizing buffer [24] and were subjected to immunoprecipitation with monoclonal anti-IR antibody ( $\alpha$ IR-1), antimouse $\mathrm{IgG}$ and pansorbin or with polyclonal antibody raised against C-terminal peptide of IR ( $\alpha$ IRC) [27] and pansorbin at $4{ }^{\circ} \mathrm{C}$. Each immune complex was washed three times with ice cold buffer (0.5\% Triton X-100, $50 \mathrm{mmol} / \mathrm{l}$ HEPES $\mathrm{pH}$ 7.4, $10 \mathrm{mmol} / \mathrm{l}$ EDTA, $1 \mathrm{mmol} / \mathrm{l}$ phenylmethylsulfonyl fluoride (PMSF), $0.3 \mathrm{~mol} / \mathrm{l} \mathrm{NaCl}$ ) and resuspended in buffer $\mathrm{A}$ (0.1\% Triton X-100, $50 \mathrm{mmol} / 1$ HEPES pH 7.4, $10 \mathrm{mmol} / 1$ $\mathrm{MgCl}_{2}, 2 \mathrm{mmol} / 1 \mathrm{MnCl}_{2}, 1 \mathrm{mmol} / \mathrm{l}$ sodium orthovanadate, and $1 \mathrm{mmol} / \mathrm{l} \mathrm{PMSF})$. Then the amount of IR contained in each immune-complex sample was normalized by ${ }^{125}$ I-insulin binding, and the immune complexes containing the same amount of IR were subjected to in vitro tyrosine-kinase assay as previously described. Samples $(50 \mu \mathrm{l})$ were incubated with or without $100 \mathrm{nmol} / \mathrm{l}$ insulin at room temperature for $30 \mathrm{~min}$, then unlabelled ATP at a final concentration of $50 \mu \mathrm{mol} / \mathrm{l}$ and $1 \mu \mathrm{Ci}$ of $\gamma{ }^{32} \mathrm{P}$ ATP was added to each sample with further incubation for $6 \mathrm{~min}$. Histone $\mathrm{H} 2 \mathrm{~b}(10 \mu \mathrm{g})$ was added and after $10 \mathrm{~min}$, the reaction was stopped by addition of Laemmli's sample buffer containing $\beta$-mercaptoethanol and boiling for $5 \mathrm{~min}$. The samples were then subjected to $15 \%$ SDS-PAGE analysis followed by alkaline hydrolysis in the gel as previously described [23-26]. The bands corresponding to histone $\mathrm{H} 2 \mathrm{~b}$ were excised and counted in a beta-counter.

\section{D irect sequencing analysis}

Genomic DNA was extracted from peripheral blood samples of the patient and the parents using the standard method. Each exon of the IR gene was amplified by polymerase chain reaction (PCR) as described by Seino et al. [28, 29]. Direct sequencing analysis was performed as described by Kadowaki et al. [30]. 


\section{Site-directed mutagenesis}

A point mutation was introduced into the expression vector $\mathrm{pSV}_{2}$-hIR carrying Ullrich's type of normal human insulin receptor cDNA [31] by the method of Kunkel [32] with one base-mismatched oligonucleotide (5'-TCCGTTCTCTGCAGCAGAGGC-3'). Transfection of the vector into Chinese hamster ovary $(\mathrm{CHO})$ cells $(\mathrm{CHO}-\mathrm{K} 1)$ and selection of clones were performed as described by Kaburagi et al. [24].

\section{Studies on transfected CH O cells (CH O - R 1092Q )}

Each experiment below was performed independently three times with a representative mutant clone (CHO-R1092Q) and wild-type clone (CHO-hIR), and the insulin binding of each clone expressing mutated or wild-type human IR was almost equal. Also another mutant clone was used to confirm the results of the following experiments.

${ }^{125}$ I-Insulin binding assays were performed as described [24-26]. For the analysis of in vitro tyrosine kinase activity, IR purified from $\mathrm{CHO}$ cells by wheat-germ agglutinin was immunoprecipitated with $\alpha$ IR-1 antibody, anti-mouse polyclonal antibody and Pansorbin. $\alpha$ IR- 1 is specific for human IR and does not precipitate native IR of CHO-K1 cells. The immunoprecipitates, containing approximately the same amount of receptors assessed by insulin binding activity, were prepared for in vitro autophosphorylation and tyrosine kinase assay as described above. The equality of content of receptors was confirmed by immunoblotting analysis using $\alpha$ IRC antibody.

Tyrosine phosphorylation of IR and insulin receptor substrate-1 (IRS-1) in intact cells was assessed by immunoprecipitation and immunoblotting with polyclonal anti-phosphotyrosine antibody as previously described [24, 26, 33]. Insulin-dependent glucose uptake was assessed by 2 -deoxyglucose uptake assay as described $[26,34]$. Measurement of thymidine incorporation into DNA was performed as described by Ando et al. [26]. Glycogen synthase assay was performed as described by Kida and Nyomba [35], and the insulin-dependent glycogen synthase activity was assessed as relative activity (\%) against the maximum obtained in the presence of a high concentration of glucose 6-phosphate [35].

\section{Studies in cultured skin fibroblasts}

Skin fibroblast cells were obtained from the patient and normal subjects. They were cultured in Dulbecco's modified Eagle's medium (DMEM; Gibco, Grand Island, NY, USA) containing $10 \%$ fetal calf serum and antibiotics at $37^{\circ} \mathrm{C}$ in a $5 \% \mathrm{CO}_{2}$ incubator. Three days after they reached confluence in $10-\mathrm{cm}$ culture dishes, cells were washed and cultured with DMEM containing $0.05 \%$ bovine serum albumin (BSA).

Tyrosine phosphorylation of IRS-1 with insulin or IGF-I stimulation was detected by immunoblotting [33]. ${ }^{14} \mathrm{C}$-glucose uptake in cultured skin fibroblasts was performed as follows. Cells were cultured in six-well plates as described above and, 3 days after they reached confluence, they were washed and starved with glucose-free DMEM containing $0.05 \%$ BSA for 16 hours. Then they were stimulated with various concentrations of insulin or IGF-I for $3 \mathrm{~h}$, followed by the incubation with $0.4 \mu \mathrm{Ci}$ of ${ }^{14} \mathrm{C}$-glucose and $0.1 \mathrm{mmol} / \mathrm{l}$ unlabelled $\mathrm{D}$-glucose for $20 \mathrm{~min}$, then washed quickly with ice cold phosphate buffered saline three times and lysed. The lysates were subjected to liquid scintillation counting.

\section{Clinical administration of IG F-I}

Recombinant human IGF-I (rhIGF-I) [36] was supplied from Fujisawa Pharmaceutical Industry, Osaka, Japan. The patient stayed in Japan with his parents during initial treatment for a month, then continued to receive the medication in his own country. IGF-I was initially administered subcutaneously at a dose of $0.1 \mathrm{mg} \cdot \mathrm{kg}$ body weight ${ }^{-1} \cdot$ day $^{-1}$, and was gradually increased with careful monitoring of blood glucose. It should be noted that the patient is only a small child being fed milk, therefore we did not measure his daily caloric intake precisely.

After 6 month's treatment he received a variety of medical investigations in his own country including physical examination, chest X-ray, echograms of heart and abdomen, and blood examination.

Prenatal diagnosis in the fifth child. During pregnancy with the fifth child, the parents hoped to have genetic information before birth. We obtained informed consent from the parents and performed amniocentesis, sampling the fluid at 17 weeks of gestation and culturing it for 7 days. Following extraction of genomic DNA and PCR amplification of the region spanning exon 18, Pst I digestion was performed on the basis of the genetic study of the family.

\section{Results}

Studies in cultured lymphocytes. The ${ }^{125}$ I-insulin binding results are shown in Figure $1 \mathrm{~A}$. Binding was $23.0 \%$ in the proband's cells, $14.0 \%$ in the father's and $13.6 \%$ in the mother's, which were within the normal range (mean $\pm S D, 26.6 \% \pm 7.1 \%, n=7$ ). There was no significant change in the affinity of the IR in the proband's and parent's cells. As shown in Figure $1 \mathrm{~B}$, autophosphorylation of IR was severely decreased in the proband's cells which were barely detected by immunoblotting. In the father's cells and the mother's cells, there was a slight difference; autophosphorylation of IR was decreased by $70 \%$ in the father's cells, and by $40 \%$ in the mother's cells. Tyrosine kinase activity of IR in $\alpha$ IRC immune-complex as shown in Figure $1 \mathrm{C}$ was markedly decreased in the proband's cells ( $\geqq 90 \%)$, and mildly or moderately decreased in the father's (70-80\%) and mother's $(50-60 \%)$. There was no significant difference in the results found using a different antibody $\alpha$ IR-1 (data not shown). Immunoblot analysis confirmed that each sample contained approximately the same amount of IR in each experiment (data not shown).

D etection of mutation in the IR gene. Direct sequencing analysis revealed that the proband was homozygous for a novel missense mutation in the tyrosine kinase domain (substitution of glutamine (CAG) for arginine (CGG) at position 1092, which amino acid number corresponds to that of Ebina's type IR cDNA [37]), and the parents were heterozygous for the mutation (data not shown). Taking advantage of the fact that this mutation creates another recognition site for restriction endonuclease Pst I 
A

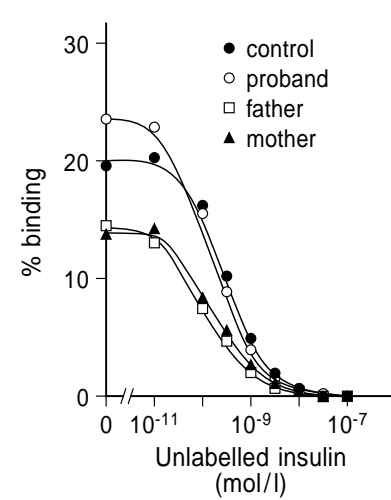

Fig. 1A-C. Studies in Epstein-Barr virus-transformed lymphocytes. A ${ }^{125}$ I-insulin binding study with transformed lymphocytes from the proband, the parents and a normal subject. The experiment was repeated independently three times and a representative result is shown. B In vitro autophosphorylation of lectin-purified insulin receptor. Tyrosine phosphorylation of the $\beta$ subunit was detected by anti-phosphotyrosine antibody and ${ }^{125}$ I-protein A. C In vitro tyrosine kinase activity of insulin receptors immunopurified from the transformed lymphocytes. The tyrosine kinase activity was measured as ${ }^{32} \mathrm{P}$ incorporation into histone H2b. The amount of IR in each sample was normalized as described in methods. C: normal control subjects; PT: patient; F: father; M: mother

(CTGCAG), the PCR products spanning exon 18 were digested with Pst I to confirm the result of sequencing analysis (data not shown).

Studies in $\mathrm{CHO}$ cells. ${ }^{125}$ I-insulin binding study revealed that the expression of the mutant IR in CHOR1092Q cells (specific insulin binding: $55 \%$ ) was almost equal to that of the wild-type IR expressing in CHO-hIR cells (specific insulin binding: $60 \%$ ), and the following Scatchard analysis indicated that the mutated IR has no difference in insulin binding affinity as compared to the normal IR (data not shown). Consistent with this, the same amount of protein fraction purified by wheat-germ agglutinin from these cells contained an equal amount of IR (Fig. 2 A). Insulin-dependent tyrosine-kinase activity of the mutant IR (Fig. 2C) as well as autophosphorylation (Fig. 2B) was severely decreased by approximately $90 \%$. Thus, severely impaired tyrosine kinase activity of the mutant IR with no significant effect on insulin binding was apparent and consistent with the study on cultured lymphocytes of the proband. Tyrosine phosphorylation of IRS-1 in CHO-R1092Q cells was severely impaired, and almost equal to that in untransfected CHO-K1 cells (Fig. 2D).

Insulin-stimulated 2-deoxyglucose uptake, thymidine incorporation into DNA, and glycogen synthase activation were all markedly impaired in
C

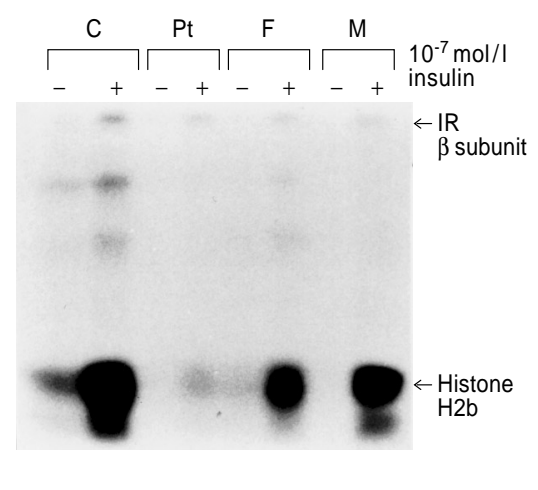

CHO-R1092Q cells as compared to CHO-hIR cells (Fig. $3 \mathrm{~A}-\mathrm{C}$, respectively). The insulin-stimulated maximal response of 2-deoxyglucose uptake and glycogen synthase activation were severely decreased in CHO-R1092Q cells. In thymidine incorporation, the maximal response was approximately the same, but the dose of insulin required to reach the half maximal response in CHO-R1092Q cells was about 100 times higher than that in CHO-hIR cells. These were consistent with the decreased tyrosine kinase activity of the mutant IR and the severely impaired tyrosine phosphorylation of IRS-1 (Fig. 2). These results suggest that the homozygous mutation in the tyrosine kinase domain of the IR is responsible for the defect in glucose metabolism and in the growth retardation of the proband.

Studies in cultured skin fibroblasts. Immunoblot analysis revealed that the amount of IR was not significantly different among the cells of the normal control and the proband (data not shown). Insulin-stimulated phosphorylation of IRS-1 was markedly decreased in the proband, whereas IRS-1 was almost normally phosphorylated by IGF-I stimulation (data not shown). To confirm that the actions of insulin and IGF-I in patient's cells correlated with the IRS-1 phosphorylation, we performed a ${ }^{14} \mathrm{C}$-glucose uptake assay to assess insulin and IGF-I action (Fig.4). In the control cells, the maximal response induced by insulin was obtained at $10 \mathrm{nmol} / \mathrm{l}$ insulin, which was approximately the same magnitude as the maximum induced by IGF-I. In contrast, ${ }^{14} \mathrm{C}$-glucose uptake stimulated by insulin in the patient's cells was markedly impaired, although sufficient glucose uptake was obtained with the stimulation of IGF-I.

Clinical course of IGF-I treatment. In the initial 1month treatment in Japan, the low dose of rhIGF-I $\left(0.1 \mathrm{mg} \cdot \mathrm{kg}^{-1} \cdot \mathrm{day}^{-1}\right)$ was effective in lowering the blood glucose level at first, but 2 or 3 days after the dose-up, more rhIGF-I was required for blood glucose control due to the increased food intake. For that reason, rhIGF-I was administered finally at a 
A

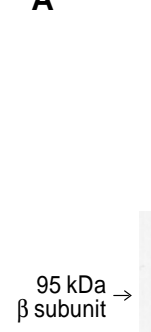

B

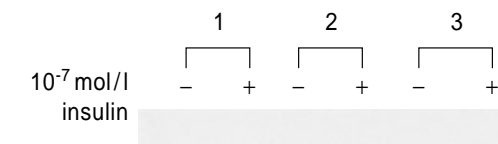

C

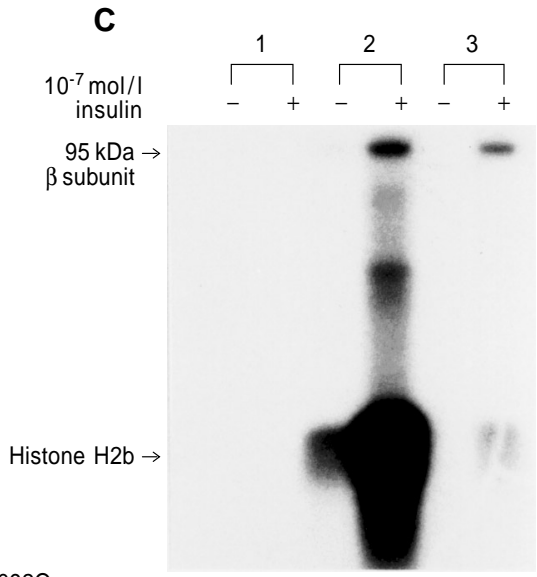

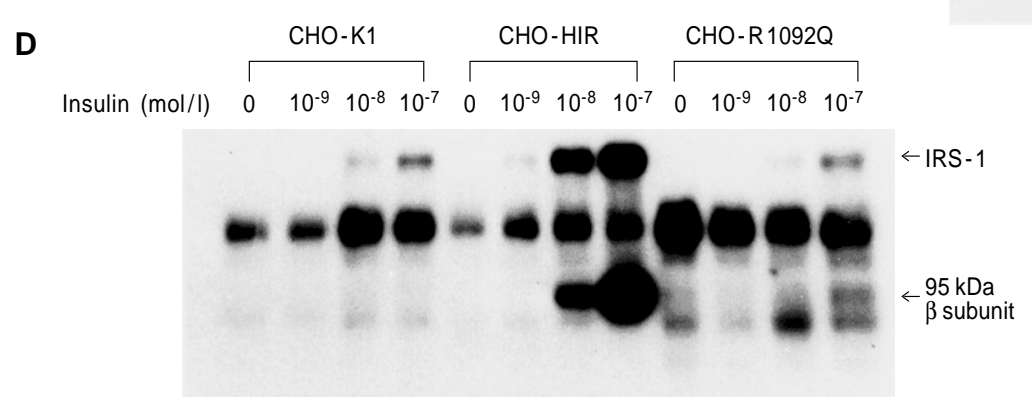

Fig. 2A - D. Tyrosine kinase activity of the mutant receptor expressed on CHO cells. A Immunoblot analysis for quantification of lectin-purified human type IR immunoprecipitated by $\alpha$ IR-1 antibody, which was subjected to experiments B and C. Lane 1: CHO-K1 (untransfected) Lane 2: CHO-hIR (wildtype) Lane 3: CHO-R1092Q (mutant-type). B In vitro autophosphorylation of the IR $\beta$ subunit. C In vitro tyrosine kinase activity of the IR. D Phosphorylation of IRS-1 in intact CHO cells. Phosphorylation of IRS-1 was markedly reduced in CHO-R1092Q, almost as little as that in CHO-K1 cells. Autophosphorylation of the receptor $\beta$ subunit in CHO-R1092Q was also impaired, but was slightly larger than that of $\mathrm{CHO}-$ $\mathrm{K} 1$, which was consistent with the data in panel $\mathrm{B}$

dose of $1 \mathrm{mg} \cdot \mathrm{kg}^{-1} \cdot \mathrm{day}^{-1}$, which was the maximum of our protocol. As indicated in Table 1, IGF-I administration was remarkably effective; the patient's fasting blood glucose levels, haemoglobin $\mathrm{A}_{1 \mathrm{c}}$ values and serum immunoreactive insulin levels were markedly improved. Moreover, his body weight increased, and his development was promoted. No adverse effects including allergy, oedema, hypoglycaemic episodes, and organomegaly were seen during the 6 months. Acanthosis nigricans and other physical features of leprechaunism did not change, nor did diabetic complications develop during this period.

Prenatal diagnosis. To determine the genotype of the fetus, Pst I digestion for PCR products was performed instead of direct sequencing [38], and the fetus was diagnosed as a heterozygote for the mutation (not shown). Based upon the correlation between genotype and phenotype in this family, we predicted that the fifth child would not have leprechaunism. In fact, the newborn was a heterozygote and did not show leprechaunism.

\section{Discussion}

To our knowledge, our case is the first to show the coexistence of two types of insulin resistance syndrome in a single pedigree. The homozygous patient with leprechaunism, and the heterozygous parents with type A insulin resistance; tyrosine kinase activity of IR in the proband's cells was markedly decreased, and that in the parent's cells was mildly or moderately decreased. Thus, a tight correlation among genotype, phenotype and tyrosine kinase activity of IR was found in this family. It is of note that this family is consanguineous, and the members have a relatively common genetic background. Therefore, our observations are highly suggestive that the severity of mutation will determine the phenotype of insulin resistance syndrome associated with IR mutations. In fact, we correctly predicted the phenotype of the newborn in prenatal diagnosis. The residue 1092 on a connecting loop between the two lobes of the $\beta$ subunit, which interact to make an open or closed form, has been suggested to be implicated in peptide substrate specificity [39]. Based upon the structure and the fact that tyrosine kinase activity was decreased by $50-75 \%$ in the heterozygous parents, the mutation is likely to act in a dominant-negative fashion. It will be of interest to see whether the newborn will develop type A insulin resistance in the future. 
A

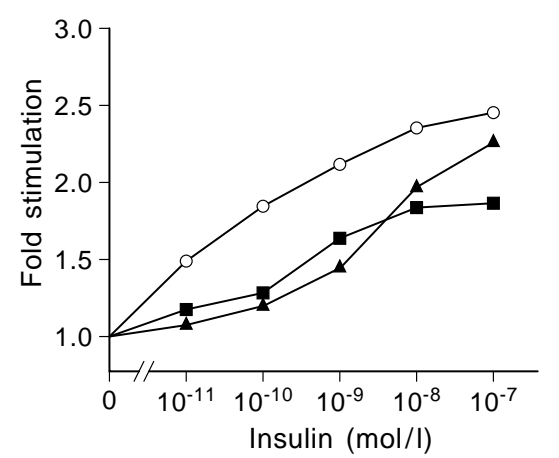

B

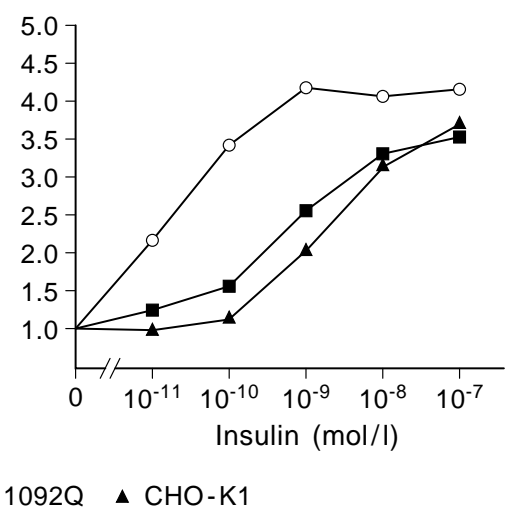

C

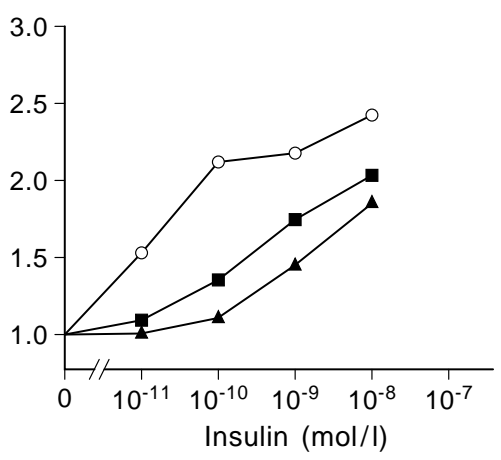

Fig. 3A-C. Biological action of insulin in intact $\mathrm{CHO}$ cells. A Two-deoxyglucose uptake. B Thymidine incorporation into DNA. C Glycogen synthase assay. All data are representative of the experiments performed independently at least three times, and the results are assessed by fold stimulation

Many patients with leprechaunism have mutations in the $\alpha$ subunit of the IR which decrease the binding affinity to insulin and/or impair IR processing [1-4]. In such cases, the intensity of signals from mutated IR to intracellular messenger molecules are

Fig. 4A - C. ${ }^{14} \mathrm{C}$-glucose uptake analysis in cultured skin fibroblasts. A shows the basal and maximal uptake of ${ }^{14} \mathrm{C}$-glucose in cells of the control subject $(\mathrm{C}, \bullet)$ and the patient $(\mathrm{Pt}, \mathrm{O})$. B and $\mathbf{C}$ show \% response at indicated doses of insulin (B) or IGF-I (C) in cells of the control subject and the patient. In the control cells $(\bullet)$, the maximal uptake with the stimulation of insulin was almost the same as the maximum with the simulation of IGF-I, while the marked impairment in insulin-stimulated ${ }^{14} \mathrm{C}$-glucose uptake was clear in the patient's cells $(\mathrm{O})$. Slight increase of ${ }^{14} \mathrm{C}$-glucose uptake by insulin in the patient's cells will be via the IGF-I receptor bound to insulin. Data are representative of three experiments diminished due to the defect in ligand-dependent activation of tyrosine kinase in the intact $\beta$ subunit and/or a decreased amount of IR on the cell surface. Three cases with leprechaunism lacking in IR have recently been reported [20-22], and insulin signalling mediated by the IR will be totally knocked out in those cases. In our case, insulin binding affinity and the amount of IR on the cell surface was within the normal range, and the results in the study of site-directed mutagenesis suggest that a selective defect in tyrosine kinase causing a severe defect in both metabolic action and growth-promoting action will be sufficient to cause leprechaunism. The case of a compound heterozygote with type A insulin resistance has been reported with a nonsense mutation in one allele and a missense mutation in the other, both of which lie in the tyrosine kinase domain [19]. In the report, tyrosine kinase activity of IR prepared from the patient's cells was decreased by $75 \%$ as compared to that from the same number of normal control cells. So we speculate that the degree of defect in insulin signalling in that case was not significantly different from those in our heterozygous case or other reported simple heterozygotes with kinase-defective mutation.
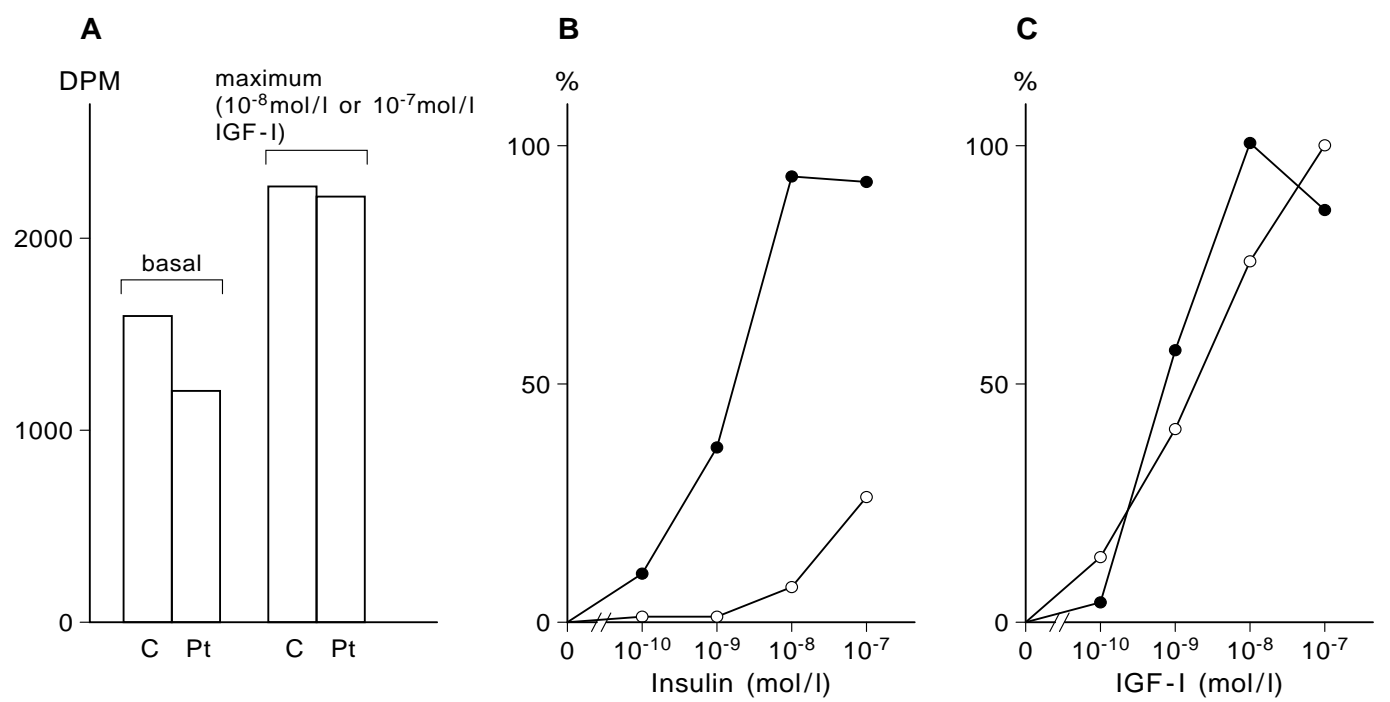
Table 1. Summary of IGF-I treatment for 6 months.

The clinical data were summarized on the patient's growth, development and diabetes

\begin{tabular}{|c|c|c|c|}
\hline & \multirow{2}{*}{$\begin{array}{l}\text { IGF-I } \\
\text { Before }\end{array}$} & \multicolumn{2}{|c|}{$1 \mathrm{mg} \cdot \mathrm{kg}^{-1} \cdot \mathrm{day}^{-1}$} \\
\hline & & After 1 month & After 6 months \\
\hline$\overline{\text { Age }}$ & $1 \mathrm{y} 10 \mathrm{M}$ & $1 \mathrm{y} 11 \mathrm{~m}$ & $2 \mathrm{y} 4 \mathrm{~m}$ \\
\hline Height $(\mathrm{cm})$ & 63 & & 70 \\
\hline Weight (kg) & 4.8 & 5.3 & 6.3 \\
\hline $\begin{array}{l}\text { Fasting blood } \\
\text { glucose }(\mathrm{mmol} / \mathrm{l})\end{array}$ & 17.2 & 8.8 & 7.7 \\
\hline FIRI (pmol/l) & 11880 & 2532 & 588 \\
\hline $\mathrm{HbA}_{1 \mathrm{c}}(\%)$ & 10 & 9.3 & 8 \\
\hline Development & $\begin{array}{l}\text { Cannot sit } \\
\text { up or speak }\end{array}$ & $\begin{array}{l}\text { Sits up with } \\
\text { a little help }\end{array}$ & $\begin{array}{l}\text { Walks with } \\
\text { a little help } \\
\text { and speaks }\end{array}$ \\
\hline
\end{tabular}

FIRI, Fasting immunoreactive insulin

We have shown the slight difference in autophosphorylation and tyrosine kinase activity of IR between the parents (Fig.1). No additional mutation has been found in the father. RT-PCR and allele-specific oligonucleotide hybridization analysis using lymphocyte mRNAs revealed an almost equal expression of the wild-type and mutant-type alleles in both of the parents (data not shown). In addition, all the receptors expressed in lymphocytes were the type described by Ullrich et al. [31]. Thus, the difference cannot be explained by the mRNA level or alternative splicing in the IR gene. Some diversity in receptor processing may modify the kinase activity, but we do not yet known the mechanism of the difference. Importantly, insulin-stimulated tyrosine phosphorylation of IRS-1 was moderately decreased but was not apparently different between the parents' skin fibroblasts (data not shown). Therefore, the difference in tyrosine kinase activity does not explain the development of diabetes only in the father despite the fact that the parents had the same heterozygous mutation. Although the dominant-negative mutation in IR is thought to be linked to type A syndrome, the development of diabetes may also be affected by additional genetic and environmental factors such as insulin secretory capacity and lifestyle apart from the IR mutation.

How can such patients almost lacking functional IR be born? We cannot completely exclude the possibility that some insulin action(s) may be mediated without the kinase activity, although this is less likely considering that the absolute requirement of IR tyrosine kinase has been well-documented for most of the insulin actions. One plausible explanation is the residual tyrosine kinase of the mutant receptor shown in Figures 1 and 2, and the patient's IR function in vivo may not be totally abolished. Another likely explanation is the compensation by the IGF-I receptor. IGF-I is known to have some insulin action in intact cells, and its receptor can phosphorylate IRS-1, which is thought to play a key role in insulin signalling $[40,41]$. In fact, Shc protein has been reported to mediate insulin action and to be involved in IGF-I receptor signalling [42]. IRS-1 and Shc bind to the GRB2/ ASH adapter protein when activated by insulin receptor or IGF-I receptor tyrosine kinase, thus the two molecules are involved in a common pathway to the activation of ras mediated by the insulin receptor and the IGF-I receptor. The IGF-I receptor is expressed early in the fetal period, and can bind to insulin although its affinity is far lower than that of the IR. After starting insulin secretion, it is possible that serum insulin level will reach 10 to 100 times that of normal and fetal insulin will bind to the IGF-I receptor. In fact, clinical administration of IGF-I to the proband was remarkably effective in glucose metabolism, growth and development. ${ }^{14} \mathrm{C}$-glucose uptake assay in skin fibroblasts as well as IGF-I-induced tyrosine phosphorylation of IRS-1 revealed a compensatory effect of IGF-I in glucose metabolism at the cellular level of the patient, which is contrary to a recent report arguing for a postreceptor defect of IGFI signalling in leprechaunism [43]. Therefore, we concluded that a common pathway via the IGF-I receptor was intact in this patient, which made a substantial contribution to his survival. It remains to be further investigated whether the heterodimerization of the mutant receptor with IGF-I receptor works in vivo.

Two patients with a homozygous nonsense mutation $[20,22]$ and another patient with a homozygous deletion [21] in the IR gene did not die in the fetal period and both showed leprechaunism. Also, targeted ablation of the IR gene in mice resulted in early neonatal death [44]. These appear consistent with our hypothesis on the fetal life of leprechaunism. Notably, the compensatory mechanism in disruption of the IR is apparently insufficient as compared to the IRS-1 knockout mice which are rescued by IRS-2 [45, 46], indicating more redundancy in intracellular signalling molecules and more critical roles for the cell surface IR in life.

Finally, we have shown the usefulness of rhIGF-I, but the dose required for the patient's treatment was quite high. We do not precisely know the long-term effect of IGF-I [36, 47] and we should carefully continue the therapy for the patient with life-threatening severe insulin resistance.

A cknowledgements. We are indebted to Dr. S.I. Taylor for helpful comments, and to Dr. Y. Gotoda and his medical staff for intensive medical care during initial IGF-I treatment for the proband in Japan.

Supported in part by a grant (192125) from the Juvenile Diabetes Foundation International to T. K. 


\section{References}

1. Taylor SI (1992) Molecular mechanism of insulin resistance. Lessons from patients with mutations in the insulin receptor gene. Diabetes 41: 1473-1490

2. Flier JS (1992) Syndromes of insulin resistance. From patient to gene and back again. Diabetes 41: 1207-1219

3. Moller DE, Flier JS (1991) Mechanism of disease: insulin resistance mechanisms, syndromes, and implications. $\mathrm{N}$ Engl J Med 325: 938-948

4. O'Rahilly S, Moller DE (1992) Mutant insulin receptors in syndromes of insulin resistance. Clin Endocrinol 36: 121132

5. Kadowaki T, Bevins CL, Cama A et al. (1988) Two mutant alleles of the insulin receptor gene in a patient with extreme insulin resistance syndrome. Science 240: 787-790

6. Yoshimasa Y, Seino S, Whittaker J et al. (1988) Insulin-resistant diabetes due to a point mutation that prevents insulin receptor processing. Science 240: 784-787

7. Kahn CR, Flier JS, Bar RS et al. (1976) The syndromes of insulin resistance and acanthosis nigricans: insulin receptor disorder in man. N Engl J Med 294: 739-745

8. Moller DE, Cohen O, Yamaguchi Y et al. (1994) Prevalence of mutations in the insulin receptor gene in subjects with features of the type A syndrome of insulin resistance. Diabetes 43: 247-255

9. Moller DE, Flier JS (1988) Detection of an alteration in the insulin-receptor gene in a patient with insulin resistance, acanthosis nigricans, and the polycystic ovary syndrome (type A insulin resistance). N Engl J Med 319: 1526-1529

10. Odawara M, Kadowaki T, Yamamoto R et al. (1989) Human diabetes associated with a mutation in the tyrosine kinase domain of the insulin receptor. Science 245: 66-68

11. Kadowaki T, Kadowaki H, Rechler MM et al. (1990) Five mutant alleles of the insulin receptor gene in patients with genetic forms of insulin resistance. J Clin Invest 86: 254264

12. Cama A, Sierra ML, Ottini L et al. (1991) A mutation in the tyrosine kinase domain of the insulin receptor associated with insulin resistance in an obese woman. J Clin Endocrinol Metab 73: 894-901

13. Kim H, Kadowaki H, Sakura H et al. (1992) Detection of mutations in the insulin receptor gene in patients with insulin resistance by analysis of single-stranded conformational polymorphisms. Diabetologia 35: 261-266

14. Taira M, Hashimoto N, Shimada F et al. (1989) Human diabetes associated with a deletion of the tyrosine kinase domain of the insulin receptor. Science 245: 63-66

15. Haruta T, Takata Y, Iwanishi M et al. (1993) Ala1048 $\rightarrow$ Asp mutation in the kinase domain of insulin receptor causes defective kinase activity and insulin resistance. Diabetes 42: 1837-1844

16. Iwanishi M, Haruta T, Takata Y et al. (1993) A mutation (Trp $1193 \rightarrow$ Leu 1193) in the tyrosine kinase domain of the insulin receptor associated with type A syndrome of insulin resistance. Diabetologia 36: 414-422

17. Accili D, Frapier C, Mosthaf L et al. (1989) A mutation in the insulin receptor gene that impairs transport of the receptor to the plasma membrane and causes insulin-resistant diabetes. EMBO J 8: 2509-2517

18. Shimada F, Taira M, Suzuki Y et al. (1990) Insulin-resistant diabetes associated with partial deletion of insulin-receptor gene. Lancet 335: 1179-1181

19. Kusari J, Takata Y, Hatada E, Freidenberg G, Kolterman O, Olefsky JM (1991) Insulin resistance and diabetes due to different mutation in the tyrosine kinase domain of both insulin receptor gene alleles. J Biol Chem 266: 5260-5267
20. Krook A, Brueton L, O'Rahilly S (1993) Homozygous nonsense mutation in the insulin receptor gene in infant with leprechaunism. Lancet 342: 277-278

21. Wertheimer E, Lu S, Backeljauw PF, Davenport ML, Taylor SI (1993) Homozygous deletion of the human insulin receptor gene results in leprechaunism. Nature Genetics 5: 71-73

22. Psiachou H, Mitton S, Alaghband ZJ, Hone J, Taylor SI, Sinclair L (1993) Leprechaunism and homozygous nonsense mutation in the insulin receptor gene. Lancet 342: 924

23. Yamamoto R, Shibata T, Tobe K et al. (1990) Defect in tyrosine kinase activity of the insulin receptor from a patient with insulin resistance and acanthosis nigricans. J Clin Endocrinol Metab 70: 869:-878

24. Kaburagi Y, Momomura K, Yamamoto-Honda R et al. (1993) Site-directed mutagenesis of the juxtamembrane domain of the human insulin receptor. J Biol Chem 268: 16610-16622

25. Yamamoto-Honda R, Koshio O, Tobe K et al. (1990) Phosphorylation state and biological function of a mutant human insulin receptor Val 996. J Biol Chem 265: 1477714783

26. Ando A, Momomura K, Tobe K et al. (1992) Enhanced insulin-induced mitogenesis and mitogen-activated protein kinase activities in mutant insulin receptors with substitution of two COOH-terminal tyrosine autophosphorylation sites by phenylalanine. J Biol Chem 267: 12788-12796

27. Izumi T, Saeki Y, Akanuma Y, Takaku F, Kasuga M (1993) Requirement for receptor-intrinsic tyrosine kinase activities during ligand-induced membrane ruffling of KB cells. J Biol Chem 263: 10386-10393

28. Seino S, Seino M, Bell GI (1990) Human insulin receptor gene: partial sequence and amplification of exons by polymerase chain reaction. Diabetes 39: 123-128

29. Seino S, Seino M, Nishi S, Bell GI (1989) Structures of the human insulin receptor gene and its characterization of its promotor. Proc Natl Acad Sci USA 86: 114-118

30. Kadowaki T, Kadowaki H, Taylor SI (1990) A nonsense mutation causing decreased levels of insulin receptor mRNA: detection by a simplified technique for direct sequencing of genomic DNA amplified by polymerase chain reaction. Proc Natl Acad Sci USA 87: 658-662

31. Ullrich A, Bell JR, Chen EY et al. (1985) Human insulin receptor and its relationship to the tyrosine kinase family of oncogenes. Nature 313: 756-761

32. Kunkel TA (1985) Rapid and efficient site-specific mutagenesis without phenotypic selection. Proc Natl Acad Sci USA 82: 488-492

33. Momomura K, Tobe K, Seyama Y, Takaku F, Kasuga M (1988) Insulin-induced tyrosine-phosphorylation in intact rat adipocytes. Biochem Biophys Res Commun 155: 11811186

34. Chou CK, Dull TJ, Russel DS et al. (1987) Human insulin receptors mutated at the ATP-binding site lack protein tyrosine kinase activity and fail to mediate postreceptor effects of insulin. J Biol Chem 262: 1842-1847

35. Kida Y, Nyomba BL (1991) Defective insulin response of cyclic adenosine monophosphate-dependent protein kinase in insulin-resistant humans. J Clin Invest 87: 673-679

36. Kuzuya H, Matsuura N, Sakamoto M et al. (1993) Trial of insulinlike growth factor I therapy for patients with extreme insulin resistance syndromes. Diabetes 42: 696-705

37. Ebina Y, Ellis L, Jarnagin K et al. (1985) The human insulin receptor cDNA. The structural basis for hormone-activated transmembrane signalling. Cell 40: 747-758 
38. Longo N, Langley SD, Griffin LD, Elsas LJ (1995) Two mutations in the insulin receptor gene of a patient with leprechaunism: application to prenatal diagnosis. J Clin Endocrinol Metab 80: 1496-1501

39. Hubbard SR, Wei L, Ellis L, Hendrickson WA (1994) Crystal structure of the tyrosine kinase domain of the human insulin receptor. Nature 372: 746-754

40. Sun XJ, Rothenberg P, Kahn CR et al. (1991) Structure of the insulin receptor substrate IRS-1 defines a unique signal transduction protein. Nature 352: 73-77

41. Kadowaki T, Koyasu S, Nishida E (1987) Tyrosine phosphorylation of common and specific sets of cellular proteins rapidly induced by insulin. J Biol Chem 262: 12821287

42. Sasaoka T, Rose DW, Jhun BH, Saltiel AR, Draznin B, Olefsky JM (1994) Evidence for a functional role of Shc proteins in mitogenic signalling induced by insulin,

Note added in proof: The patient is now 5 years old and still on IGF-I treatment. His weight is $10.5 \mathrm{~kg}$, and his height $82 \mathrm{~cm}$. Physical examination apart from the features of leprechaunism is unremarkable. insulin-like growth factor-1, and epidermal growth factor. J Biol Chem 269: 13689-13694

43. Backeljauw PF, Alves C, Eidson M, Cleveland W, Underwood LE, Davenport ML (1994) Effect of intravenous insulin-like growth factor I in two patients with leprechaunism. Pediatr Res 36: 749-754

44. Accili D, Drago J, Lee EJ et al. (1996) Early neonatal death in mice homozygous for a null allele of the insulin receptor gene. Nat Genet 12: 106-109

45. Tamemoto H, Kadowaki T, Tobe K et al. (1994) Insulin resistance and growth retardation in mice lacking insulin receptor substrate-1. Nature 372: 182-186

46. Araki E, Lipes MA, Patti M-E et al. (1994) Alternative pathway of insulin signalling in mice with targeted disruption of the IRS-1 gene. Nature 372: 186-190

47. Kolaczynski JW, Caro JF (1994) Insulin-like growth factor1 therapy in diabetes: physiologic basis, clinical benefits, and risks. Ann Intern Med 120: 47-55 